\title{
UPAYA MENINGKATKAN PRESTASI BELAJAR MELALUI PENINGKATAN KECERDASAN SPIRITUAL SANTRI PONDOK PESANTREN
}

\author{
Wira Hadi Kusuma \\ Institut Agama Islam Negeri (IAIN) Bengkulu \\ wirahadi@iainbengkulu.ac.id
}

\begin{abstract}
ABSTRAK
Tujuan penelitian ini adalah untuk menganalisis upaya meningkatkan prestasi belajar melalui peningkatan kecerdasan spiritual dalam meningkatkan prestasi belajar santri Pondok Pesantren Amanatul Ummah Pacet Mojokerto. Metode penelitian, penelitian ini merupakan penelitian lapangan (field research) dengan pendekatan kualitatif deskriptif. Alat pengumpulan data melalui wawancara, observasi dan dokumentasi. Analisis data melalui reduksi data, penyajian hasil dan penarikan kesimpulan. Hasil penelitian, didapatkan informasi jika peningkatan kecerdasan spiritual pada santri bisa dilakukan dengan 7 cara atau upaya yang dilakukan para Kiai dan Ustad di pondok pesantren yaitu sungguh-sungguh (istiqomah), banyak berpuasa, melaksanakan shalat malam, membaca alquran, membiasakan berwudu', meninggalkan kemaksiatan, dan tidak boleh jajan sembarangan. Simpulan, peningkatan kecerdasan spiritual yang diajarkan kepada santri memiliki dampak positif terhadap peningkatan prestasi belajar.
\end{abstract}

Kata Kunci: Kecerdasan Spiritual, Prestasi Belajar, Spiritualistas Santri

\begin{abstract}
The purpose of this study was to analyze efforts to improve learning achievement through increasing spiritual intelligence in increasing student learning achievement. The research method, this research is a field research with a qualitative approach, with data collection tools through interviews, observation and documentation. The results of the study, in general, that the spirituality of students has an impact on improving student learning achievement. This is done in 7 ways or efforts made by the Kiai and Ust, namely earnest (istiqomah), fasting a lot, performing night prayers, reading the Koran, accustoming ablution, leaving immorality, and should not be indiscriminate snacks. In conclusion, the increase in santri's spiritual intelligence has a positive impact on improving learning achievement.
\end{abstract}

Keywords: Spiritual Intelligence, Learning Achievement, Santri Spiritualistas 


\section{PENDAHULUAN}

Relasi manusia entitas agama dan proses kejiwaan tidak dapat dipisahkan satu sama lain, pengakuan manusia terhadap sesuatu yang ada diluar dirinya (transendensi) atau kekuatan supranatural, sadar atau tidak akan terjadi. Dalam konteks masyarakat agama, tidak jarang perilaku keseharian lebih ditentukan oleh hasil pengalaman atas keyakinan agama, dalam artian perilaku yang terjadi dalam kehidupan praksis manusia merupakan manifestasi atas keyakinan terhadap tuhannya (Kusuma, 2014).

Tujuan pendidikan nasional pada hakikatnya adalah untuk membangun manusia Indonesia seutuhnya. Pengertian "manusia seutuhnya" adalah manusia yang berkembang ketiga aspek dalam dirinya, yaitu aspek intelligence quotient (IQ), emotional quotient (EQ) dan spiritual quotient (SQ). Dari ketiga aspek ini, pengembangan SQ bertujuan untuk membangun mental spiritual warga Indonesia yang kokoh, sehingga mereka memiliki integritaskepribadian yang baik yang dapatmenunjang keberhasilan pembangunan (Yanuarti, 2018).

Dari hasil penelitian menunjukkan bahwa kecerdasan spiritual berpengrauh positif terhadap motivasi belajar, terdapat pengaruh langsung yang signifikan kecerdasan spiritual terhadap prestasi belajar matematika, yaitu terdapat pengaruh langsung variabel bebas kecerdasan spiritual (X1) terhadap variabel bebas motivasi belajar (X2). Besar kontribusi pengaruh langsung kecerdasan spiritual $(\mathrm{X} 1)$ terhadap motivasi belajar $(\mathrm{X} 2)$ adalah $\mathrm{KD}=\mathrm{P} 122 \times 100 \%=0,667$ x 0,667 x $100 \%=44,45 \%$ (Basuki, 2015). Penelitian lain sebagaimana dilakukan Sholiha dkk menjelaskan bahwa kecerdasan spiritual yang memiliki indikator pengenalan diri sendiri, pengendalian diri, motivasi, empati dan keterampilan sosial berpengaruh terhadap kinerja guru SMP An-Nur Bululawang (Sholihah, 2017).

Sejalan dengan penelitian tersebut, hasil observasi pada tanggal 5 Oktober 2018 yang penulis lakukan di lembaga Pendidikan yaitu Pesantren Amanatul Ummah Pacet Mojokerto, menjumpai para santri yang memiliki prestasi baik tingkat lokal maupun global dan internasional. Misalnya pada tahun 2018 Pesantren ini meraih penghargaan sebagai Pesantren Modern Inspiratif, penghargaan Santri of the Year, penghargaan kategori The Most Favorite Islamic School of The Year 2017 dan The Best Tutoring Program in Islamic School 2018.

Dengan demikian, maka kemampuan tenaga pendidik dalam merencanakan dan melaksanakan proses pembelajaran merupakan faktor utama dalam mencapai tujuan pengajaran. Untuk meningkatkan kualitas dan kuantitas proses pembelajaran yang dilakukan oleh tanaga pendidik, maka tenaga pendidik harus memiliki kompetensi dan mampu menguasai proses pembuatan perencanaan kegiatan belajar mengajar, pelaksanaan kegiatan pembelajaran yang direncanakan, dan melakukan penilaian terhadap hasil dari proses belajar mengajar, yang selanjutnya harus dikuatkan nilai-nilai kecerdasan spiritual (Fitriani dan Yanuarti, 2018). Berangkat dari masalah di atas, maka dalam tulisan ini penulis akan 
mendeskripsikan tentang upaya meningkatkan hasil belajar melalui peningkatan kecerdasan spritual terhadap santri di Pesantren Amanatul Ummah.

Secara konseptual kecerdasan spiritual terdiri dari gabungan kata kecerdasan dan spiritual. Kecerdasan berasal dari kata cerdas yaitu sempurna perkembangan akal budi untuk berfikir dan mengerti (Depdikbud, 2014). Sedangkan spiritual berasal dari kata spirit yang berasal dari bahasa latin yaitu spritus yang berarti nafas. Kecerdasan spiritual adalah kecerdasan jiwa yang membantu seseorang untuk mengembangkan dirinya secara utuh melalui penciptaan kemungkinan untuk menerapkan nilai-nilai positif. Ciri utama dari kecerdasan spiritual ini ditunjukkan dengan kesadaran seseorang untuk menggunakan pengalamannya sebagai bentuk penerapan nilai dan makna, yang meliputi mutlak jujur, keterbukaan, pengetahuan diri, fokus pada konstribusi diri, spiritual non dogmatis (Putra \& Latrini, 2018).

Sedangkan makna lain dari spirit, yaitu terdapat beberapa makna, misalnya dalam Kamus Besar Bahasa Indonesia dijelaskan bahwa spirit memiliki arti semangat, jiwa, sukma dan roh. Dan spiritual diartikan sesuatu yang berhubungan dengan atau bersifat kejiwaaan (jiwa atau rohani).Dalam kamus bahasa yang berjudul Salim's Ninth Collegiate English-Indonesian Dictionary,kata spirit dicari arti etimologisnya. Ada sepuluh arti bila spirit diperlakukan sebagai kata benda (noun). Lalu bila spirit diperlakukan sebagai kata kerja (verb) atau kata sifat (adjective) ada beberapa arti pula mengenainya.

Makna Kecerdasan Spiritual (SQ) dalam pandangan Danah Zohar adalah kecerdasan yang bertumpuh pada bagian dalam tubuh manusia yang berhubungan dengan kearifan di luar ego, atau jiwa sadar. Inilah yang digunakan manusia bukan hanya untuk mengetahui nilai-nilai yang ada, melainkan juga untuk secara kreatif menemukan nilai-nilai baru (Syafri, 2018).

Ary Ginanjar menjelaskankecerdasan spiritual adalah kemampuan untuk memberi makna spiritual terhadap pemikiran, setiap perilaku dan kegiatan, melalui langkah-langkah dan pemikiran yang bersifat fitrah, menuju manusia yang seutuhnya dan memiliki pola pemikiran tauhid, serta berprinsip hanya karena Allah, yang kecerdasan bahwa kecerdasan spiritual (SQ) adalah kecerdasan tertinggi (Syafri, 2018).

Dari beberapa definisi tersebut, dapat dipahami kecerdasan spiritual merupakan kecerdasan yang sudah ada dalam setiap manusia sejak lahir yang membuat manusia menjalani hidup ini dengan penuh makna, selalu mendengarkan suara hati nuraninya, tidak pernah merasa sia-sia, semua yang dijalaninya selalu bernilai. spiritualitas dapat membantu seseorang untuk membangun dirinya secara utuh. Semua yang dijalaninya tidak hanya berdasarkan proses berfikir rasio saja tapi juga menggunakan hati nurani. Dalam konteks itulah, hati menjadi elemen penting dalam kecerdasan spiritual, sehingga nilainilai spiritual yang dilaksanakan seperti di Pesantren Amanatul Ummah menjadi spirit untuk meningkatkan kemajuan lembaga pendidikan itu sendiri. 
Prestasi belajar adalah hasil yang telah dicapai dari yang telah diakukan, dikerjakan, dan sebagainya.Prestasi merupakan hasil dari usaha-usaha untuk mencapai tujuan yang dimiliki oleh individu-individu dengan tujuan meraih kesuksesan dalam setiap tugas yang diberikan (Wibowo, 2017). Dari pengertian di atas dapat diambil kesimpulan bahwa prestasi adalah hasil dari suatu kegiatan seseorang atau kelompok yang telah dikerjakan, diciptakan dan menyenangkan hati yang diperoleh dengan jalan bekerja.

\section{METODE PENELITIAN}

Penelitian ini merupakan dengan pendekatan kualitatif deskriptif dan tergolong penelitian lapangan (field research) jika dilihat dari lokasi penelitian. Alat pengumpulan data dalam penggalian informan pengumpulan data yaitu observasi, wawancara, dokumentasi dan sebagainya (Nata, 2015). Dengan tehnik analisis data melalui reduksi data, penyajian hasil dan penarikan kesimpulan.

\section{HASIL DAN PEMBAHASAN \\ Sistem Pembelajaran}

Sistem pembelajaran di pesantren ini secara umum menerapkan pola pendidikan umumnya di pesantren. Namun untuk mata pelarajan inti yang diajarkan adalah matematika, fisika, biologi kimia, dan bahasa Inggris disampaikan dan diujikan dalam Bahasa Inggris sedang mata pelajaran Agama \& Bahasa Arab disampaikan dan diujikan dalam Bahasa Arab. Setiap kelas rata-rata terdiri dari 25 siswa dan komunikasi sehari-harinya menggunakan bahasa Arab dan bahasa Inggris kecuali hari Ahad. (Wawancara, 6 Oktober 2018). Pembelajaran dimulai sejak 02.30 WIB, yang diawali dengan shalat tahajut berjamaah dan teruskan dengan membaca alquran, shalat subuh dan kajian kitab (Observasi, 4-6 Oktober 2018). Dalam pelaksanaanya pemaduan sistem belajar modern dan tradisional, sehingga sistem ini menjadi menarik dan menghasilkan lulusan yang berkualitas.

\section{Prestasi Belajar Santri}

Pembiasaan aktifitas spiritual terutama pada saat shalat tahajud, tasbih dan duha, memiliki dampak yang cukup signifikan dalam meningkatkan prestasi santri pesantren Amanatu Ummah hingga tingkat internasional (Observasi dan Wawancara melalui Kiai Asep, 6 Oktober 2018). Sang kyai dengan semangat mengatakan kami menjamin santri lulus $100 \%$ berklasifikasi A dengan penuh kejujuran dan percaya diri dan lulusannya diterima di perguruan tinggi sesuai pilihannya baik di dalam maupun di luar negeri (www.mbi-au.sch.id, 10 Maret 2019). Para santri dengan mudah diterima di UGM, ITB, UI, ITS, UNAIR, UB, STAN, dan perguruan tinggi dalam dan luar negeri. Ada juga yang diterima di Maroko, Rusia, Jepang, Turki, dan Australia. 
Temuan penelitian yang juga mengejutkan bahwa prestasi siswa baik tingkat nasional maupun internasional semuanya di publikasikan melalui media online, spanduk-spanduk, dan pengumuman serta pamplet-pamplet lainnya yang bertujuan memberi motivasi bagi santri yang lain dalam menggapai prestasi belajar.

Dimensi spiritualitas dalam Islam berkaitan secara langsung dengan realitas Ilahi, Tuhan Yang Maha Esa (tauhid). Spiritualitas merupakan inti (core) kemanusiaan itu sendiri. Spiritualitas agama berkenaan dengan kualitas kesadaran, perasaan, moralitas, dan nilai-nilai luhur lainnya yang bersumber dari ajaran agama. Spiritualitas agama bersifat Ilahiah, bukan bersifat humanistik lantaran berasal dari Tuhan, (Rahmawati, 2016).

Jalaludin Rakhmat mengutip lima karakteristik orang yang cerdas secara spiritual menurut Roberts A.Emmons dalam bukunya 'The Psychology of Ultimate Concerns': Pertama, kemampuan untuk mentrandensikan yang fisik dan material; kedua, kemampuan untuk mengalami tingkat kesadaran yang memuncak; ketiga, kemampuan untuk mensakralkan pengalaman seharihari; keempat, kemampuan untuk menggunakan sumber-sumber spiritual untuk menyelesaikan masalah dan kemampuan untuk berbuat baik; kelima, memiliki rasa kasih sayang yang tinggi pada sesama makhluk Tuhan (Rahmawati, 2016).

Berangkat teori di atas, prestasi belajar santri di Pesantren dapat ditingkat melalui kedekatan kepada Allah swt. Adapun upaya yang dilakukan dalam meningkatkan spiritualitas santri dengan menerapkan 7 amalan rutin yang diyakini menjadi modal dasar (Kiai Asep, wawancara, 6 Oktober 2018).

Pertama, bersungguh-sungguh dan ajeg dalam berkesungguhan (al-jiddu wal muwaadlabah). Santri harus selalu dimotivasi untuk bisa melakukan segala sesuatu. Motivasi ini sering kali disampaikan kepada santri dalam setiap momen berkumpul, belajar, sebelum tidur, yang lebih dalam dilaksanakan setiap selesai sholat tahajud, duha, dan hajat berjamaah. Motivasi melalui doa, misalnya, "jadikanlah anak-anak kami berprestasi dan bersungguh-sungguh". "Jadikan anak kami lulus pada tes masuk perguruan tinggi di Jepang”. Itu antara lain kalimat doa setiap habis shalat tahajud, duha dan hajat, yang diaminkan oleh para Ustazd, santri dan pegawai lainnya yang berjumlah lebih kurang 10.000 orang setiap hari berjamaah (Observasi, 5 Oktober 2018). Aktifitas demikian terus dilaksanakan secara konsisten untuk meningkatkan kecerdasan siswa dalam hal motivasi. Dalam teori spiritualitas hal ini dapat dikategorikan memiliki kesadaran yang tinggi dalam melakukan berbagai aspek, yang dilakukan karena Tuhan yang kuasa, Allah SWT

Kedua, menyedikitkan makan (taqliilul ghida). Para santri tidak boleh sampai kenyang. Sebab kenyang itu datang 10 menit kemudian. Kenyang itu menghilangkan kecerdasan. Sehingga para santri dilatih puasa senin-kamis dan puasa pertengahan bulan Hijriyah. Para santri juga dibiasakan untuk menggunkan piring dengan ukuran kecil dan menyiapkan petugas untuk membagikan makan 
dengan porsi yang cukup agar tidak terlalu kenyang. Menurut Kiai Asep, telah menjadi tradisi para santri makan sedikit karena akan mengurangi kecerdasan fisik dan jiwa. Orang yang banyak makan akan cenderung malas, ngantuk dan mengurangi semangat (Wawancara, 6 Oktober 2018). Jika dikaitkan dengan teori bahwa kontrol diri dan menjaga diri dari hal-hal yang berlebihan.

Ketiga, selalu menjaga diri dalam keadaan suci dengan berwudlu (mudaawamatul wudlu'). Para santri dianjurkan untuk selalu dalam keadaan suci dan berwudlu, karena dengan wudu' akan mencerdaskan dan akan menjaga diri serta jiwa seseorang dari hal-hal yang syubhat bahkan yang makruh. Semakin tinggi tingkat kesadaran menjaga kesucian diri dan jiwa, maka akan meninggikan kualitas kecerdasan spiritual seseorang. Para santri yang sudah batal wudlu karena berbagai alasan dengan sadar untuk segera mengambil wudlu kembali, agar keberkahan dan keutamaan dapat mereka terima. Membaca aspek ini dalam perspektif kecerdasan spiritual adalah upaya menjaga kesucian diri, sehingga orang yang suci akan mencapai puncak kesadaran, (Rahmawati, 2016).

Dari segi kesehatan, percikan dari air wudhu bisa membuat otot yang tegang menjadi lebih rileks sekaligus membersihkan kotoran yang menempel pada tubuh khususnya bagian wajah. Wudhu yang dilakukan secara rutin bisa dijadikan solusi terbaik untuk menjaga kesehatan tubuh. Rasulullah SAW bersabda, Sesungguhnya saudara-saudara kami itu akan datang dalam keadaan putih cemerlang karena wudhu dan aku yang akan membimbing mereka ke telaga. (Riwayat Muslim).

Keempat, membaca Al-Quran dengan melihat teks bacaannya (qira'atul qurani nadzran. Waktu pembacaannya 15 menit sehabis azan Subuh sampai iqamat, 15 menit harus baca Al-Qur'an," dalam surat Yunus: 57, dijelaskan bahwa; "Hai manusia, sesungguhnya telah datang kepadamu pelajaran dari Tuhanmu". Dari aya ini menjelaskan bahwa Al-Quran tidak hanya berisi tentang ibadah antara makhluk dengan Pencipta-Nya,tapi di dalamnya juga sarat akan ilmu pengetahuan. Membaca al-Quran dengan melihat teks diyakini para santri dapat meningkatkan ketenangan dan konsentrasi, sehingga dapat kecerdasan spiritual, emosional dan intelektual. Aspek ini dapat dirasakan melalui pengalaman langsung dan aktualisasi diri dalam meyakini ayat-ayat-Nya.

Kelima, tidak boleh bermaksiat (tarkul ma'aashi). Ilmu adalah cahaya yang dinyalakan Allah di dalam hati seorang hamba, dan maksiat mematikan cahaya tersebut. Sehingga para santri, kiai, guru dan para pegawai untuk dilatih melaksanakan aktivitas spiritual yang tinggi, serta berusaha menjauhi kemaksiatan walaupun kecil. Kiai Asep menjelaskan bahwa kegelisahan yang dirasakan pelaku maksiat di dalam hatinya, dan hilangnya ketenangan dari dalam hati; Allah akan mempersulit setiap urusan dalam hidupnya; menimbulkan sifat lemah baik pada agama dan badannya, sehingga pelaku maksiat terasa berat dan malas untuk melakukan ketaatan; dan maksiat menghilangkan keberkahan umur dan melenyapkan kebaikannya. Dalam penerapannya para santri selalu dihimbau 
untuk menjaga pandangan antara santri wati dan santriwan (wawancara, 6 Oktober 2018). Menjaga diri terhadap aturan agama adalah aspek moral dalam spiritualitas seseorang, sehingga kesadaran akan mentaati aturan Allah swt.

Keenam, melaksanakan shalat malam. Berdasarkan kajian teologis bahwa shalat tahajud dapat mengangkat derajat manusia ketempat yang mulia dan dapat mendatangkan ketenangan bagi yang melaksanakannya. Secara teoritis bahwa terdapat korelasi antara shalat tahajud dengan kecerdasan spiritual. Pelaksanaan shalat tahajud merupakan keharusan yang dilaksanakan sejak pukul 02.30 WIB dini hari, yang dilaksanakan sebanyak 11 rekaat, hingga pelaksanaan shalat Subuh. Pada kegiatan shalat malam ini menjadi media yang sangat efektif menanamkan, menumbuhkan dan mengembangkan kecerdasan spiritual para santri khususnya dalam mencapai prestasi belajar, dari tingkat lokal, nasional, hingga tingkat internasional. Menjalankan nilai-nilai dak aktivitas spiritual

Ketujuh, tidak boleh jajan di luar. Jajan di luar itu kan terbuka, banyak orang yang melihatnya, lalu ingin, namun tidak bisa membeli karena tidak punya uang. Kalau makanan terkondisikan seperti itu, hilang berkahnya. Hal itu disebutnya sebagai cara santri bertawakkal.

Selain beberapa upaya yang menjadi ciri inti di pondok pesantren Amanatul Ummah, beberapa langkah strategis yang menunjang dalam mewujudkan dan meningkatkan prestasi santri di tingkat lokal, Nasional dan Internasional. Adapun strategi tersebut yaitu;Pertama: komitmen mutu dan pendidikan karakter. Sistem pendidikan dilaksanakan secara ketat dan bertanggung jawab, unggul, utuh, dan terjangkau oleh seluruh lapisan masyarakat yang berminat. Komitmen ini senantiasa disosialisasikan ke calon orang tua/wali, termasuk ditegaskan dalam sejumlah brosur-brosur. Kedua: sistem Dauroh (Repetisi). Para santri yang belajar di lembaga pendidikan pesantren, selalu diminta untuk mengulang berkali-kali sepulang sekolah di bawah bimbingan guru pendamping senior. Jika ada murid yang tidak menguasai kompetensi yang ditargetkan, guru pendamping inilah yang mendapatkan teguran keras, bukan muridnya. Ketiga: Strategi differensiasi Produk. Pesantren menyadari, tidak semua siswa memiliki kompetensi dan minat yang sama. Agar mereka tertarik memilih sekolah sesuai dengan minat dan kemampuannya, maka diberikan pilihan produk yang beragam.

\section{SIMPULAN}

Upaya yang dilakukan dalam meningkatkan prestasi belajar santri dengan menjalankan tujuh prinsip rahasia secara kontinyu, yaitu istiqomah dan bersungguh-sungguh, membaca al-Quran dengan melihat teksnya, menjaga wudhu, meninggalkan kemaksiatan, menyedikitkan makan, melaksanakan shalat malam, dan tidak jajan (belanja) di khalayak umum (karena akan mengurangi keberkahan, jika ada orang yang melihat makan/minum tetapi mereka tidak mampu membelinya). Peningkatan kecerdasan spiritual ini memiliki efek positif 
terhadap peningkatan prestasi santri pesantren Amanatul Ummah.Penanaman dan pembiasaan kecerdasan spiritual santri di pondok pesantren Amanatul Ummah memiliki efek yang sangat signifikan, hal ini terbukti dengan meningkatnya kualitas lulusan, prestasi lulusan masuk perguruan tinggi, akreditasi kampus, dan kemampuan daya serap santri lulusan dapat dengan mudah diterima dilembagalembaga pendidikan yang ternama, baik tingkat nasional maupun tingkat internasional.

\section{DAFTAR PUSTAKA}

Agustian, A.,G. (2015) Rahasia Sukses Membangun Kecerdasan Emosi dan Spiritual ESQ The ESQ Way 165 Edisi Revisi, Jakarta: Arga

Depdikbud. (2014). Kamus Besar Bahasa Indonesia, Jakarta:

Fitriani, A \& Eka, Y. (2018). Upaya Guru Pendidikan Agama Islam Dalam Menumbuhkan Kecerdasan Spiritual Siswa, Jurnal BELAJEA: Jurnal Pendidikan Islam, 3 (2); 173-202.

Kusuma, W.,H. (2014). Memahami Agama secara Psikologis dan Relasinya dalam Upaya Resolusi Konflik, Jurnal SYI'AR, 16.

Nata, A. (2015). Metode Studi Islam, Edisi Revisi. Jakarta: Raja Grafindo Persada.

Putra, K., A., S \& Latrini, M., Y. (2016). Pengaruh Kecerdasan Intelektual, Kecerdasan Emosional, Kecerdasan Spiritual, Komitmen Organisasi Terhadap Kinerja Auditor. e-Jurnal Akuntansi Universitas Udayana Vol.17(2); 1168-1195.

Rahmawati, U. (2016). Pengembangan Kecerdasan Spiritual Santri: Studi terhadap Kegiatan Keagamaan di Rumah Tahfiz Quran Deresan Putri Yogyakarta. Jurnal Penelitian, Vol. 10(1)

Sholiha, M., Sunaryo, H \& Priyono, A., A. (2017). Pengaruh Kecerdasan Emosional dan Kecerdasan Spiritual Terhadap Kinerja Guru Smp An-Nur Bululawang - Malang, Jurnal Warta Ekonomi Vol. 07(17)

Syafri, F. (2017). Memahami Perkembangan Psikologi Keagamaan Anak Usia Dini, Jurnal Al-Fitrah, 1(2)

Wibowo, A. (2017). Pengaruh Pendekatan Pembelajaran Matematika Realistik dan Saintifik terhadap Prestasi Belajar, Kemampuan Penalaran Matematis dan Minat Belajar SMP Negeri 1 Kelumpang Hilir. Jurnal Riset Pendidikan Matematika ISSN 2356-2684 (print), ISSN 2477-1503 (online).

Yanuarti, E. (2017). Pemikiran Pendidikan Ki. Hajar Dewantara dan relevansinya Dengan Kurikulum 13, Jurnal Penelitian STAIN Kudus, http://journal.stainkudus.ac.id/index.php/jurnalPenelitian/article/view/3489 